\title{
Lipoprotein Metabolism by Rat Hepatomas Studies on the Etiology of Defective Dietary Feedback Inhibition of Cholesterol Synthesis
}

\author{
Graham F. Barnard, Sandra K. Erickson, \\ and Allen D. Cooper \\ Department of Medicine, Stanford University School of Medicine, \\ Stanford, California 94305
}

bstract. In contrast to normal liver, it is known that in vivo hepatomas fail to decrease their rate of cholesterol biosynthesis in response to increased dietary cholesterol. From a consideration of the available data it has been hypothesized that the defect might lie in the delivery of cholesterol to the hepatoma cell. To study this further, lipoprotein interactions with rat hepatoma cells in tissue culture (HTC $7288 \mathrm{C}$ ) and with the same cell line in vivo were investigated. HTC cells grown in a medium containing $10 \%$ calf serum exhibited saturable, specific, calcium-dependent binding of rat ${ }^{125} \mathrm{I}$-chylomicron remnants at $4^{\circ} \mathrm{C}$ with half maximal saturation at $4.8 \mu \mathrm{g}$ protein $/ \mathrm{ml}$ and maximum binding of $96 \mathrm{ng}$ protein $/ 10^{6}$ cells. At $4^{\circ} \mathrm{C}$, HTC cells also bound human ${ }^{125} \mathrm{I}$-low density lipoprotein (LDL) specifically, but bound it with a much lower affinity. These cells also exhibited specific binding for rat LDL and rat hypercholesterolemic very low density lipoprotein (VLDL). All these lipoproteins were degraded by HTC cells. Thus, it was concluded that hepatoma cells possess lipoprotein receptors that recognize and process LDL, VLDL, and chylomicron remnants.

Overnight incubation of HTC cells in lipid-depleted medium containing $0.5 \mu \mathrm{M}$ compactin increased binding of rat chylomicron remnants and of hypercholesterolemic VLDL $\sim 1.7$-fold without a significant change in binding affinity. LDL binding also increased, by $\sim 3$.5-fold. These

Portions of this work were presented at the Western section of the American Federation for Clinical Research at Carmel, CA, in 1982 and 1983, and at the Federation of American Societies for Experimental Biology meetings in New Orleans, LA, in 1982.

Dr. Cooper was the recipient of Research Career Development Award AM 00503 from the National Institutes of Health. Dr. Barnard was the recipient of an American Liver Foundation summer fellowship. 1984.

Received for publication 19 April 1983 and in revised form 9 March

J. Clin. Invest.

(c) The American Society for Clinical Investigation, Inc. 0021-9738/84/07/0173/12 $\$ 1.00$

Volume 74 , July 1984, 173-184 changes were also observed when binding and internalization were measured at $37^{\circ} \mathrm{C}$.

After HTC cells were incubated in lipid-depleted medium, the rate at which $\left[{ }^{14} \mathrm{C}\right]$ acetate was incorporated into $\left[{ }^{14} \mathrm{C}\right]$ cholesterol increased 2.5 -fold. Inclusion of rat chylomicron remnants at 5-10 $\mu$ g protein $/ \mathrm{ml}$ prevented this increase in acetate incorporation or, if added after culture in lipid-depleted medium, reduced the increased levels back to control values. However, the rate of acetate incorporation into cholesterol by cells grown in complete medium was not decreased to levels below base line by rat chylomicron remnants. Inclusion of human LDL only partially prevented the rise or only partially reduced the increased levels back to control and did not reduce control levels below base line. Hypercholesterolemic VLDL, which contain more cholesterol per particle than chylomicron remnants, did reduce $\left[{ }^{14} \mathrm{C}\right]$ acetate incorporation to below control levels. Therefore, the intracellular mechanism for down regulation of cholesterol synthesis by lipoproteins is intact in these cells.

Based on these results we hypothesized that a relative lack of lipoprotein receptors expressed by hepatomas in vivo in comparison with those expressed by normal liver would explain the apparent absence of feedback inhibition of cholesterol synthesis. Consistent with this hypothesis, the binding of chylomicron remnants to liver cell membranes was 3-5 times greater than to membranes from tumors grown in vivo subcutaneously or intramuscularly. Membranes from tumor cells grown in vitro bound remnants least well. It is proposed that the relative lack of receptors places the hepatoma at a disadvantage in competing with the liver for lipoproteins of dietary origin and may account for the lack of feedback regulation of cholesterol synthesis in hepatomas.

\section{Introduction}

The rate of cholesterol synthesis in normal liver is determined in part by the amount of cholesterol in the diet. When dietary 
cholesterol content increases, the rate of hepatic cholesterol biosynthesis decreases, and vice versa. This process is referred to as feedback regulation (1). Dietary cholesterol is transported to the liver in lipoproteins that are called chylomicron remnants (2-4). Current evidence suggests that the hepatocyte surface has a receptor that recognizes apolipoprotein $\mathrm{E}(5-8)$, which is an important constituent of the chylomicron remnant. After binding, the lipoprotein particle is degraded with hydrolysis of esterified lipid (3,9-11) and, as with other cell types (12), the liberated free cholesterol then modulates the rate of cholesterol synthesis primarily at the level of 3-hydroxy-3-methylglutaryl coenzyme A (HMG CoA) $)^{1}$ reductase, which is the rate-limiting enzyme of cholesterol biosynthesis $(13,14)$.

Siperstein (15) observed that the rate of cholesterol biosynthesis in Morris hepatomas grown subcutaneously in rats was not inhibited by increasing the amount of cholesterol in the diet. This was true for a large number of transplantable rat hepatomas (16), rat primary hepatocellular carcinomas (17), and was also observed in human hepatomas (16). The defect in the tumors was independent of the basal rate of cholesterol biosynthesis, which ranged from levels higher than that of normal liver to $<10 \%$ of the normal rate (15). In addition, livers from rats treated with hepatic carcinogens also exhibited this abnormality of regulation even before malignant change was morphologically evident (18).

Because the regulation of cholesterol biosynthesis is a multistep process, there are a number of potential sites at which such a defect could occur. Despite many investigations in the past, the defect has not yet been precisely identified. When HMG CoA reductase was partially purified from hepatoma cells and its physical and biochemical properties were compared with the enzyme from normal liver, no differences were found (19), which suggested that the enzyme per se is not altered to a major extent. Although it has been suggested that there is a defect in the coupling of cell cholesterol content to enzyme behavior in hepatomas, this change was seen in the host livers as well (20). Mevalonolactone injected in vivo suppressed HMG CoA reductase in hepatomas (21). Since the action of mevalonolactone depends at least in part upon its conversion to sterol, this suggested that the regulatory mechanism for HMG CoA reductase by sterols was functional. Furthermore, when hepatoma cells were grown in tissue culture (HTC 7288C), their reductase activity and their rate of sterol synthesis were decreased by the presence of 25-hydroxycholesterol or by high concentrations of low density lipoprotein (LDL) in the medium (22). Reductase activity increased when these cells were cultured in the absence of sterols. These observations further supported the concept that the intracellular mechanism of HMG-CoA reductase regulation was qualitatively intact.

Taken together, these studies suggested that the defect in feedback regulation relates to the delivery of cholesterol to the

1. Abbreviations used in this paper: HTC, hepatoma cells in tissue culture; HMG CoA, 3-hydroxy-3-methylglutaryl coenzyme A; LDM, lipid-depleted medium; PMSF, phenylmethylsulfonyl fluoride. site at which synthesis is regulated. Harry et al. (23) proposed this based on their observation that less intragastrically administered ${ }^{3} \mathrm{H}$-cholesterol was found in intramuscularly grown hepatomas than in the liver of the same rat. However, similar experiments with primary hepatomas showed only small differences in ${ }^{3} \mathrm{H}$-cholesterol uptake $(17,24)$. Further, Bierne and Watson (25) observed that HTC cells that had shown regulation in vitro were no longer responsive to dietary cholesterol feedback when transplanted back in vivo. On the basis of these observations we hypothesized that a defect in the number or types of lipoprotein receptors expressed by hepatomas could account for the lack of feedback regulation in the tumor.

The purpose of the present investigation was to identify and examine the nature of the lipoprotein receptors present on the surface of HTC cells, to determine whether the receptors are regulated and whether they are capable of transporting adequate amounts of cholesterol to initiate feedback inhibition of cholesterol biosynthesis, and finally to compare the numbers of receptors expressed in vivo by hepatomas and normal livers (26-28).

\section{Methods}

Materials. $1-{ }^{14} \mathrm{C}-$ Acetic acid (sodium salt, $45-60 \mathrm{mCi} / \mathrm{mmol}$ ) was purchased from New England Nuclear (Boston, MA), and ${ }^{125} \mathrm{I}$ (15 mCi/ $\mu \mathrm{g})$ came from Amersham Corp., Arlington Heights, IL. Swim's S-77 tissue culture medium, L-glutamine, L-cystine, antibiotic mixture (penicillin, streptomycin, nystatin), and trypan blue solution were from Gibco Laboratories, Grand Island, NY. Siliclad was from Clay-Adams, Parsippany, NJ, and bovine serum albumin (fatty acid free) came from Calbiochem-Behring Corp., San Diego, CA. Compactin (ML-236B) sodium salt was a gift of Dr. Millie Wiley, University of California, San Francisco, CA. Suramin was obtained from Mobay Chemical Corp., NY. All other chemicals were reagent grade. HTC cells derived from rat liver minimal deviation hepatoma $7288 \mathrm{C}$ were obtained from the Cell Culture Facility at the University of California, San Francisco.

Methods. Tissue culture media. Complete growth medium consisted of Swim's S-77 medium supplemented with L-glutamine $(298 \mathrm{mg} / \mathrm{l})$, Lcystine $(13.8 \mathrm{mg} / \mathrm{l})$, phenol red $(10 \mathrm{mg} / \mathrm{l})$, and tricine $(0.05 \mathrm{M})$. The $\mathrm{pH}$ was adjusted to 7.8 with $1 \mathrm{~N} \mathrm{NaOH}$ before the medium was sterilized by ultrafiltration (Nalgene filter 450-0020, Nalgene Labware Div. Nalge/ Sybron Corp., Rochester, NY). After sterilization, sterile $10 \%$ calf serum and sterile antibiotic mixture $(10 \mathrm{ml} / \mathrm{l})$ were added.

Lipid-depleted medium (LDM) was the same as complete medium except that the calf serum was lipid depleted by centrifuging whole calf serum at $d=1.21$ to remove lipoproteins. The upper $5 \mathrm{ml}$ of each $20-\mathrm{ml}$ tube was collected as serum lipoproteins. The serum fractions were dialyzed three times against $6 \mathrm{~L}$ of $0.9 \% \mathrm{NaCl}$ at $4^{\circ} \mathrm{C}$, sterilized by ultrafiltration, and stored at $-20^{\circ} \mathrm{C}$ until use. The cholesterol content of LDM and complete medium were determined by gas liquid chromatography (29). Compactin, ML 236B, was prepared from the lactone at $\sim 0.46 \mathrm{mM}$ concentration (30) and was sterilized by ultrafiltration through a $0.45-\mu$ millipore filter before addition to the growth media.

Culture of HTC cells. Cells as obtained from the tissue culture facility (usually in midlog growth phase) were diluted 2-3 fold into complete medium to yield a density of $2-3 \times 10^{5}$ cells $/ \mathrm{ml}$ in $150 \mathrm{ml}$ total volume. They were grown in sealed serum bottles, with stirring (spinner culture) for $48 \mathrm{~h}$ before transfer into fresh medium. Cell number was determined 
by counting an aliquot of cells in a hemocytometer and viability was determined by trypan blue exclusion after incubation of cells in $0.9 \mathrm{ml}$ phosphate-buffered saline (PBS) plus $0.1 \mathrm{ml}$ trypan blue solution. Cells were harvested for experiments or for transfer to a different medium by sedimentation at $100 \mathrm{~g}$ for $8 \mathrm{~min}$, after which they were resuspended in the desired medium. The cells had a doubling time of $24-30 \mathrm{~h}$ in complete medium. The growth rate was not significantly altered by growing the cells in LDM for 24-48 h. However, when compactin was included in the LDM medium, the majority of the cells died by $72 \mathrm{~h}$; therefore, experiments were performed after 17-24 h using cells grown in LDM plus compactin. The cells, when grown in basal medium, contained $373 \pm 36 \mu \mathrm{g}$ protein $/ 10^{6}$ cells $(n=7)$ and $5.82 \pm 2.2 \mu \mathrm{g}$ total cholesterol $/ 10^{6}$ cells $(n=5)$.

Preparation of lipoproteins. Rat chylomicrons were collected from animals with a lymph duct cannula as described previously (31). Chylomicron remnants were prepared in eviscerated rats as described previously $(11,32)$. Rat hypercholesterolemic VLDL $(d=1.006-1.019)$ and $\mathrm{HDL}_{\mathrm{c}}(d=1.019-1.080)$ were prepared as described previously from rats fed an atherogenic diet (32). Human LDL came from serum of normolipidemic volunteers after a 14-h fast and was isolated by centrifugation according to Sigurdsson et al. (33). The composition of the lipoproteins used in these studies has previously been reported by this laboratory $(32,34)$. Rat $\operatorname{LDL}(d=1.022-1.050)$ was prepared from the plasma of 83 rats. Sodium azide $(0.04 \%)$ and EDTA $(1 \mathrm{mM})$ were added to the plasma and its density was adjusted to 1.063 by the addition of solid KBr. After centrifugation at $100,000 \mathrm{~g}$ for $16 \mathrm{~h}$ the fraction $d$ $<1.063$ was removed, dialyzed against PBS that contained azide/EDTA, and the density was readjusted to 1.022 by the addition of solid $\mathrm{KBr}$. Centrifugation at $100,000 \mathrm{~g}$ for $16 \mathrm{~h}$ floated the VLDL and IDL which were removed. The density of the lower layer was adjusted to 1.050 by the addition of solid $\mathrm{KBr}$ and was recentrifuged through an upper band of PBS of 1.050 density to isolate the LDL. The LDL was removed and dialyzed against PBS. The rat $\mathrm{LDL}$ contained $3.6 \mathrm{mg}$ protein $/ \mathrm{ml}, 0.8$ $\mathrm{mg}$ cholesterol $/ \mathrm{mg}$ protein, and $2.55 \mathrm{mg}$ triglyceride $/ \mathrm{mg}$ protein. SDS gel electrophoresis on $7.5 \%$ acrylamide gels followed by densitometric scanning of the Coomassie Blue stained gels showed that $86 \%$ of the visible protein migrated as apo $\mathrm{B}$, with $5 \%$ at the dye front (which may include the $\mathrm{C}$ and $\mathrm{A}$ apoproteins) and $3 \%$ as apo $\mathrm{E}$. The lipoproteins were radioiodinated by the iodine monochloride method as previously described (32). With triglyceride-rich lipoproteins, $90-95 \%$ of the ${ }^{125} \mathrm{I}-$ label was precipitated with an equal volume of $20 \%$ trichloroacetic acid, while with LDL, 97-99\% was trichloroacetic acid precipitable (35).

Lipoprotein binding studies. HTC cells were innoculated into 100 $\mathrm{ml}$ of appropriate growth medium, complete medium or LDM, at a density of $\sim 4 \times 10^{5}$ cells $/ \mathrm{ml}$ and were grown for $20 \mathrm{~h}$ at $37^{\circ} \mathrm{C}$ before each experiment. The cells were harvested and washed once in Dulbecco's PBS which contained $50 \mu \mathrm{M} \mathrm{CaCl}_{2}$ and $20 \mathrm{mg} / \mathrm{ml}$ bovine serum albumin. Final resuspension was in $\mathrm{PBS}$ at $4^{\circ}$ or $37^{\circ} \mathrm{C}$ at a concentration of $\sim 7.8$ $\times 10^{7}$ cells $/ \mathrm{ml}$. Binding assays were performed in glass tubes that were coated with $1 \%$ siliclad and albumin $(20 \mathrm{mg} / \mathrm{ml}$ in PBS buffer). Reaction mixtures contained $3.9 \times 10^{5}$ cells, ${ }^{125}$ I-labeled lipoproteins, unlabeled lipoproteins, and EDTA in amounts as described in the legends to the figures. The final volume was $200 \mu \mathrm{l}$ and was made up with S-77 medium that contained no lipoproteins. Incubations at $4^{\circ}$ or $37^{\circ} \mathrm{C}$ for $1 \mathrm{~h}$ with shaking were started by the addition of HTC cells and terminated by the transfer of the tube contents to a $400-\mu$ l polyethylene microfuge tube coated with Siliclad and albumin. The tubes were centrifuged at $12,000 \mathrm{rpm}$ for $2 \mathrm{~min}$ at $4^{\circ} \mathrm{C}$ in a Beckman Microfuge model 152 (Beckman Instruments Inc., Fullerton, CA). The supernatant was either discarded or analyzed for trichloroacetic acid soluble reaction products
(35). The cell pellet was resuspended in $75 \mu 1$ of PBS and layered onto $250 \mu \mathrm{l}$ of $100 \%$ calf serum which was contained in a siliconized $400-\mu \mathrm{l}$ microfuge tube. These tubes were centrifuged at $12,000 \mathrm{rpm}$ for $5 \mathrm{~min}$ at $4^{\circ} \mathrm{C}$ and the supernatant was removed. The base of the tube containing the pellet was cut off and the radioactivity was determined in a gamma counter. The measured radioactivity was normalized to the number of cells per incubation, which was determined by counting the cells after the final resuspension at harvesting.

Lipoprotein degradation. HTC cells grown in complete medium (40 $\mathrm{ml}$ at $6 \times 10^{5}$ cells $/ \mathrm{ml}$ ) were harvested by centrifugation at $500 \mathrm{~g}$ for $10 \mathrm{~min}$, washed once in PBS, and resuspended in $5 \mathrm{ml}$ of LDM. Aliquots of $600 \mu \mathrm{l}\left(2.4 \times 10^{6}\right.$ cells $)$ were added to each of four scintillation vials that contained $5.4 \mathrm{ml}$ of LDM and a small stir bar. Incubations were started as indicated in the figure legend by the addition of ${ }^{125}$ I-labeled lipoprotein $(24-87 \mu \mathrm{l}$ vol $)$ and continued at $37^{\circ} \mathrm{C}$ with stirring. At various times, $700-\mu \mathrm{l}$ aliquots were removed into $1-\mathrm{ml}$ capacity microfuge tubes on ice and were centrifuged at $12,000 \mathrm{rpm}$ for $5 \mathrm{~min}$. To the supernatants, $20 \mu \mathrm{l}$ of bovine serum albumin $(20 \mathrm{mg} / \mathrm{ml})$ followed by $700 \mu \mathrm{l}$ of $20 \%$ trichloroacetic acid were added. The suspensions were vortexed, left on ice for not $<30 \mathrm{~min}$, and centrifuged at $10,000 \mathrm{~g}$ for $10 \mathrm{~min}$. The supernatants were transferred to a fresh tube and $5 \mu \mathrm{l}$ of $40 \% \mathrm{KI}$ and $50 \mu \mathrm{l}$ of $30 \% \mathrm{H}_{2} \mathrm{O}_{2}$ were added. The solutions were extracted with 0.7 $\mathrm{ml}$ of chloroform and the upper aqueous layer was counted for radioactivity in a $\gamma$-counter.

Synthesis of cholesterol from $\left[{ }^{14} \mathrm{C}\right]$ acetate. HTC cells grown in either complete medium or LDM for $20 \mathrm{~h}$ were harvested and resuspended in $20 \mathrm{ml}$ of fresh medium, and the cell number was counted. Aliquots containing $\sim 1.3 \times 10^{7}$ cells were transferred to sterile Gibco (Gibco Laboratories) culture flasks (100-ml capacity with stirring bar), lipoproteins sterilized by passage through a millipore filter were added ( $0.5-$ $2.0 \mathrm{ml}$ ), and the volume was made up to $25 \mathrm{ml}$ by the addition of the appropriate medium. The flasks were closed and incubated with stirring for $2-4 \mathrm{~h}$ at $37^{\circ} \mathrm{C}$ and then $\left[{ }^{14} \mathrm{C}\right]$ acetate (specific activity $2 \mu \mathrm{Ci} / \mu \mathrm{mol}$ ) was added to give a final concentration of $0.2 \mathrm{mM}$. Incubation was continued for $7 \mathrm{~h}$. The cell numbers were counted and then $40 \mathrm{ml}$ of $95 \%$ ethanol, $6.5 \mathrm{ml}$ of $33 \% \mathrm{KOH}, 1 \mathrm{mg}$ of carrier cholesterol in ethanol, and $36,000 \mathrm{cpm}$ of ${ }^{3} \mathrm{H}$-cholesterol as internal standard were added to each flask. After standing overnight at $4^{\circ} \mathrm{C}$, the sealed samples were incubated at $90^{\circ} \mathrm{C}$ for $3 \mathrm{~h}$, cooled, and then extracted three times with $30 \mathrm{ml}$ of petroleum ether (boiling point $30-60^{\circ} \mathrm{C}$ ). The pooled ether extracts were washed with $10 \mathrm{ml}$ of $0.1 \mathrm{~N} \mathrm{KOH}$ and the washed ether phase dried down to $\sim 0.5 \mathrm{ml}$ under a stream of nitrogen. The ether extracts were plated on silica gel $\mathrm{H}$ thin layer chromatography plates that were developed with benzene/ethyl acetate (4:1) (36). The cholesterol $\left(0.3 R_{\mathrm{f}}\right)$ was visualized by iodine vapor and after decolorization the cholesterol band was scraped from the plate and counted in $10 \mathrm{ml}$ of Aquasol liquid scintillation fluid. Conversion of $\left[{ }^{14} \mathrm{C}\right]$ acetate to cholesterol is expressed as $\mathrm{cpm}$ in cholesterol per 7-h incubation per $10^{7}$ cells after correction for losses using the ${ }^{3} \mathrm{H}$-cholesterol internal standard. Cells were counted both at the beginning of the incubation period and at the end of the incubations. Because cell number increased during this period the average cell number was used in the calculations.

Growth of tumors in vivo. HTC cells were grown in complete medium as detailed above. $300-\mathrm{ml}$ batches of cells $\left(4-6 \times 10^{5}\right.$ cells $\left./ \mathrm{ml}\right)$ were harvested by centrifugation, washed once in sterile PBS, and resuspended in $2.5 \mathrm{ml}$ of PBS by passage through a 27 -gauge needle. Buffalo rats $(180-200 \mathrm{~g})$ were injected subcutaneously into one thigh and intramuscularly into the other thigh with $1.4 \times 10^{7}$ cells/injection. After 18 d all rats had tumors.

Preparation of cell membranes. (a) HTC cell membranes. Membranes 
were prepared and lipoprotein binding studies to them were carried out by a modification of the method of Basu et al. (37). Actively growing HTC cells in $300-\mathrm{ml}$ batches $\left(3-6 \times 10^{5}\right.$ cells $\left./ \mathrm{ml}\right)$ were harvested by centrifugation at $100 \mathrm{~g}$ for $5 \mathrm{~min}$. They were washed once by resuspension in $50 \mathrm{ml}$ sterile Dulbecco's medium followed by centrifugation. They were resuspended in $7.5 \mathrm{ml}$ hypotonic buffer at $4^{\circ} \mathrm{C}(10 \mathrm{mM}$ Tris/ $\mathrm{HCl}$, pH 7.4, $1 \mathrm{mM} \mathrm{CaCl}_{2}$ with $1 \mathrm{mM}$ phenylmethylsulfonyl fluoride [PMSF]) and after $10 \mathrm{~min}$ were homogenized first with 10 strokes of a motor driven Potter-Elvehjem homogenizer and then with 10 strokes of a hand held Potter-Elvehjem homogenizer. Whole cells were sedimented at 500 $g$ for $5 \mathrm{~min}$, the pellet was resuspended in $7.5 \mathrm{ml}$ hypotonic buffer, and the homogenization and centrifugation were repeated. The supernatants were adjusted to isotonicity by addition of $8.7 \% \mathrm{NaCl}$. The sample was centrifuged at $105,000 \mathrm{~g}$ for $30 \mathrm{~min}$ to give the cell membrane pellet. This pellet was resuspended in $0.5 \mathrm{ml}$ isotonic buffer, homogenized by three strokes in a ground glass homogenizer, and $200 \mu$ l were transferred into each of four Airfuge tubes (Beckman Instruments Inc.). Centrifugation at $29 \mathrm{psi}$ in an Airfuge (Beckman Instruments Inc.) for $10 \mathrm{~min}$ gave the final pellet. After removal of the supernatant it was stored frozen until assayed for lipoprotein binding activity.

(b) Liver and tumor cell membranes. Rats were anesthetized with ether, samples of blood were withdrawn from the abdominal aorta, and then 2-3-g samples of freshly excised liver or tumor tissue were added to $8-10 \mathrm{ml}$ of buffer $(10 \mathrm{mM}$ Tris/ $\mathrm{HCl}, \mathrm{pH} 7.4,150 \mathrm{mM} \mathrm{NaCl}, 1 \mathrm{mM}$ $\mathrm{CaCl}_{2}$, and $1 \mathrm{mM}$ PMSF) and homogenized with 10 strokes of a motor driven Potter-Elvehjem homogenizer followed by six strokes with a hand held Potter-Elvehjem homogenizer. The suspension was centrifuged for $10 \mathrm{~min}$ at $500 \mathrm{~g}$, the supernatant was respun at $500 \mathrm{~g}$ and then the new supernatant was centrifuged at $105,000 \mathrm{~g}$ for $30 \mathrm{~min}$. The membrane pellet was resuspended in $8 \mathrm{ml}$ of buffer, homogenized with five strokes of a Dounce homogenizer, and recentrifuged at $105,000 \mathrm{~g}$ for $20 \mathrm{~min}$. The pellet was resuspended in $1.0 \mathrm{ml}$ of buffer (without PMSF) and 200- $\mu$ l aliquots were transferred to airfuge tubes for centrifugation at $29 \mathrm{psi}$ in an airfuge (Beckman Instruments Inc.) for $10 \mathrm{~min}$. After removal of the supernatant the pellet samples were stored frozen until assayed.

Assay of lipoprotein binding to cell membranes. Aliquots of cell membranes from liver, intramuscular tumor, subcutaneous tumor, or HTC cells containing $1.6-4 \mathrm{mg}$ protein were resuspended in $200 \mu \mathrm{l}$ buffer $\left(10 \mathrm{mM}\right.$ Tris/ $\mathrm{HCl}$, pH 7.5, $50 \mathrm{mM} \mathrm{NaCl}$, and $\left.1 \mathrm{mM} \mathrm{CaCl}_{2}\right)$ by passage 10 times through a 27 -gauge needle. Protein content was determined on 1-, 2-, or 5- $\mu$ l samples using a micro method based on that of Lowry et al. (38) with bovine serum albumin as reference protein. Lipoprotein binding assays were carried out in $200 \mu$ l total volume in microfuge tubes. The incubation mixture contained buffer ( $50 \mathrm{mM}$ Tris/ $\mathrm{HCl}, \mathrm{pH} 7.5,100 \mathrm{mM} \mathrm{NaCl}$, and $0.5 \mathrm{mM} \mathrm{CaCl}_{2}$ ) cell membranes (150$180 \mu \mathrm{g}$ protein), $\left[{ }^{125} \mathrm{I}\right]$ chylomicron remnants, and $0-30 \mu \mathrm{g}$ protein $/ \mathrm{ml}$ (specific activity equals $360 \mathrm{cpm} / \mathrm{ng}$ ); $0.2 \mathrm{mM}$ suramin or 15 times protein excess of nonradioactive chylomicron remnants over the radioactive sample were used to determine nonspecific binding. Tubes were incubated at $37^{\circ} \mathrm{C}$ with inversion of tube contents each $15 \mathrm{~min}$ for a total of $60 \mathrm{~min}$. The tubes were then centrifuged in a model 152 microfuge (Beckman Instruments Inc.) for $5 \mathrm{~min}$; the surface of the pellet was washed 2 times with $10 \%$ sucrose and the pellet was counted for ${ }^{125} \mathrm{I}$ radioactivity. Control incubations contained either no membranes, 0.2 mM suramin, or nonradioactive chylomicron remnants.

In preliminary experiments it was found that virtually all of the membrane protein was recovered in the pellet with this centrifugation procedure. Suramin, which has previously been shown to reverse LDL binding to its specific receptor in human skin fibroblasts (39), competes for the remnant binding site to about the same degree as a 20-fold excess of unlabeled remnants but will not compete for the nonspecific binding of remnants and phospholipid (unpublished observations). Thus, suramin was used to quantify nonspecific binding in selected experiments to conserve unlabeled remnants. Several experiments in each group were done using 20-fold excess unlabeled remnants and the results always correlated well with those obtained with suramin.

\section{Results}

Surface binding of rat chylomicron remnants to HTC cells. Binding of chylomicron remnants to cultured hepatoma cells was studied at $4^{\circ} \mathrm{C}$ where internalization and degradation are negligible. The binding of ${ }^{125} \mathrm{I}$-chylomicron remnants to HTC cells at $4^{\circ} \mathrm{C}$ is shown in Fig. $1 \mathrm{~A}$. Nonspecific binding was determined by measuring the amount of binding in the presence of a 20-fold excess of nonradioactive chylomicron remnants (top) or in the presence of $4 \mathrm{mM}$ EDTA (bottom). Specific binding was defined as the total minus the nonspecific binding at each lipoprotein concentration. The specific binding of ${ }^{125} \mathrm{I}$-remnants to HTC cells at $4^{\circ} \mathrm{C}$ was virtually the same whether EDTA or a 20-fold excess of unlabeled remnants were used. The binding was readily detectable at a low remnant concentration. The abolition of $80 \%$ of total binding by $4 \mathrm{mM}$ EDTA (bottom) suggests that the remnant binding requires $\mathrm{Ca}^{++}$. Supplementation with additional calcium (up to $1 \mathrm{mM}$ ) did not increase the observed total binding (not shown). Further characterization
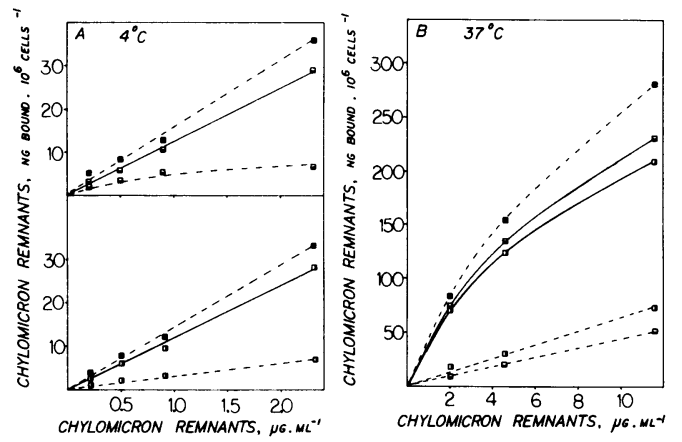

Figure 1. Binding of rat chylomicron remnants to HTC cells at $4^{\circ} \mathrm{C}$ and at $37^{\circ} \mathrm{C}$. HTC cells were grown in complete medium, harvested, and resuspended in $100 \mathrm{ml}$ of complete medium at about $3 \times 10^{5}$ cells $/ \mathrm{ml}$. After $20 \mathrm{~h}$ the cells were harvested, washed in PBS, and binding assays were performed using $3.9 \times 10^{5}$ cells in $200 \mu \mathrm{l} \mathrm{vol}$ in glass tubes as detailed in Methods. The final ${ }^{125}$ I-chylomicron remnant concentrations were $0.2-12 \mu \mathrm{g} / \mathrm{ml}$ (specific activity, 250-450 $\mathrm{cpm} / \mathrm{ng}$ ). Control incubations contained either $4 \mathrm{mM}$ EDTA or a 20 fold protein excess of nonradioactive chylomicron remnants, as indicated. Incubations of $1 \mathrm{~h}$ duration were started by the addition of

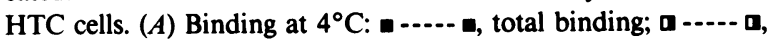
binding in the presence of $4 \mathrm{mM}$ EDTA (bottom); a-a, specific binding equals total minus EDTA resistant binding; $\square-.-.-\square$, binding in the presence of a 20 -fold excess of chylomicron remnants (top); $\square-\square$, specific binding equals total minus nonspecific binding. $(B)$ Binding at $37^{\circ} \mathrm{C}$, symbols as in Fig. $1 \mathrm{~A}$. 
of this binding site is given below. The results show that HTC cells possess cell surface receptors that recognize chylomicron remnants.

Binding and internalization of rat chylomicron remnants by HTC cells. Binding of ${ }^{125} \mathrm{I}$-remnants to HTC cells at $37^{\circ} \mathrm{C}$ is illustrated in Fig. $1 \mathrm{~B}$. As was observed at $4^{\circ} \mathrm{C}$, a similar pattern of specific binding is obtained whether EDTA or an excess of nonradioactive remnants was used to estimate nonspecific binding. Specific binding at $37^{\circ} \mathrm{C}$ was consistently higher than that observed at $4^{\circ} \mathrm{C}$ (an average of 5.2-fold higher in five experiments). Since, at $37^{\circ} \mathrm{C}$, cell-associated radioactivity includes ${ }^{125}$ I-labeled lipoprotein that has been internalized into the cell and that which has been degraded and remains in the cell, the observed increase represents a metabolic component not observed at $4^{\circ} \mathrm{C}$ as well as any temperature dependent increase in binding. Thus, consistent with studies in other cell types (10, 40), remnants are internalized and degraded at $37^{\circ} \mathrm{C}$ but not at $4{ }^{\circ} \mathrm{C}$. HTC cells also bound rat ${ }^{125} \mathrm{I}$ apo $\mathrm{E}$ rich high density lipoprotein $\left(\mathrm{HDL}_{\mathrm{c}}\right)$, giving a curve very similar to that observed with ${ }^{125}$ I-remnants in Fig. $1 B$ (data not shown).

Binding and metabolism of human LDL by HTC cells. Since remnants that contain apo E can bind to both $\mathrm{LDL}(\mathrm{B}, \mathrm{E})$ receptors and remnant (E) receptors it was important to further characterize the specificity of the receptor. For this purpose, studies were undertaken initially using human LDL. It is known that human LDL binds to the rat fibroblast LDL receptor, but that it does so with a lower affinity $(41,42)$. Studies presented below compare some aspects of human and rat LDL metabolism by HTC cells and confirm the fact that although the use of human LDL may underestimate the affinity of HTC cell LDL receptors, the binding qualitatively reflects that of rat LDL.

The binding pattern to HTC cells observed with human LDL was different from that observed with remnants (Fig. 2). Much higher concentrations of LDL than of remnants were required to achieve measurable specific binding at $4^{\circ} \mathrm{C}$. At a concentration of $200 \mu \mathrm{g} \mathrm{LDL}$ protein $/ \mathrm{ml}, 20 \mathrm{ng} / 10^{6}$ cells were bound (Fig. $2 A$ ). The binding obtained with human LDL at $37^{\circ} \mathrm{C}$ was threefold higher $(n=5)$ than that observed at $4^{\circ} \mathrm{C}$ (Fig. 2 B). Presumably this was due to the presence of both internalized and partially degraded LDL as well as of surface bound LDL. Another contrast between LDL and remnant binding was observed with EDTA. At $4^{\circ} \mathrm{C}$, EDTA was not as effective in reducing $\mathrm{LDL}$ binding as a 20 -fold excess of unlabeled lipoprotein, which suggests that some $\mathrm{Ca}^{++}$independent binding was being measured. In the experiments performed at $37^{\circ} \mathrm{C}$, the nonspecific binding as determined using either EDTA or a 20-fold excess of unlabeled LDL gave very similar results, which was in contrast to what was observed at $4^{\circ} \mathrm{C}$. Taken together, these data suggest that HTC cells also express a receptor that specifically recognizes LDL, albeit with a lower affinity than for remnants.

Competition of human $L D L$ and rat chylomicron remnants for the lipoprotein receptor(s) present on the HTC cell. Because HTC cells bound both remnants and LDL specifically, it was
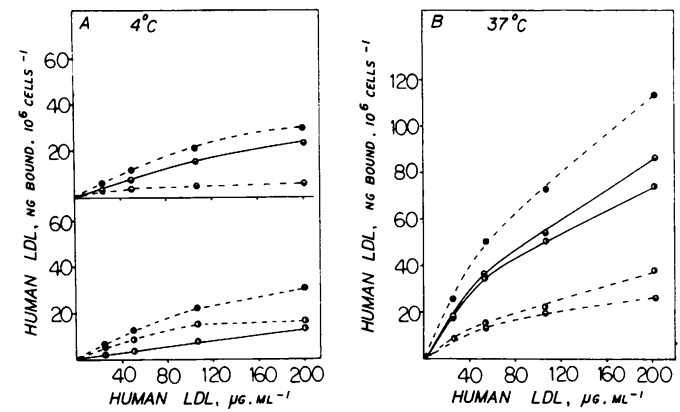

Figure 2. Binding of human LDL to $\mathrm{HTC}$ cells at $4^{\circ} \mathrm{C}$ and $37^{\circ} \mathrm{C}$. Cells were prepared and grown in complete medium as detailed in the legend to Fig. 1 and in Methods. The final human ${ }^{125}$ I-LDL concentrations were $25-200 \mu \mathrm{g}$ protein/ml (specific activity $200-390$ $\mathrm{cpm} / \mathrm{ng}$ ) and controls contained either $4 \mathrm{mM}$ EDTA or a 20 -fold excess of unlabeled human LDL protein as indicated. Incubations of 1 $\mathrm{h}$ duration were started by the addition of HTC cells. $(A)$ Binding at $4^{\circ} \mathrm{C}$ : $\bullet$, total binding; $\odot . . . .0$, nonspecific binding in the presence of $4 \mathrm{mM}$ EDTA (bottom); $\bullet-0$, specific binding equals total minus nonspecific EDTA binding; $\odot . . .-\odot$, nonspecific binding in the presence of a 20-fold protein excess of human LDL (top); $\bullet-\odot$, specific binding equals total minus nonspecific human LDL binding. (B) Binding at $37^{\circ} \mathrm{C}$, symbols as used in $A$.

of interest to determine whether the same or different receptor populations are involved. To study this question the competition of the two lipoprotein moieties with one another was investigated. Competitive binding studies at $4^{\circ} \mathrm{C}$ are shown in Fig. 3. Binding of $2.6 \mu \mathrm{g}^{125} \mathrm{I}$-remnants $/ \mathrm{ml}$ is illustrated alone and in the presence of an excess of either nonradioactive remnants, human LDL, or rat $\mathrm{HDL}_{\mathrm{c}}$ (a lipoprotein that is enriched in apo E) (Fig. 3 A). A $50 \%$ reduction of ${ }^{125} \mathrm{I}$-remnant binding required a threefold excess of remnants, a twofold excess of $\mathrm{HDL}_{\mathrm{c}}$, or a 90 -fold protein excess of human LDL. Thus, human LDL competed with remnant binding, but did so very poorly. Moreover, while remnants competed for $>90 \%$ of remnant binding, even at high concentrations, LDL did not compete for $>62 \%$ of the remnant binding.

The converse experiment was also carried out. Using $50 \mu \mathrm{g} /$ $\mathrm{ml}$ of human ${ }^{125} \mathrm{I}-\mathrm{LDL}$, a $50 \%$ reduction of LDL binding required a fivefold protein excess of nonradioactive LDL but only a 0.06 fold excess of remnants (Fig. $3 \mathrm{~B}$ ). Thus, remnants were far more effective in competing for LDL binding than was LDL itself on a total protein basis. Taken together, these results suggest that remnants and LDL share at least one recognition site, although there may be a second remnant-specific site as well.

Lipoprotein binding and metabolism by cells grown in LDM. The data presented thus far were obtained with cells grown in complete medium that contained $10 \%$ calf serum. Because it has been shown that other cell types express more receptors for LDL when they are grown in LDM (43), the binding of lipoproteins to HTC cells grown in LDM was investigated. The cholesterol content of this medium was only $2.6 \%$ that of the complete medium. In addition, the HTC cells were grown for 

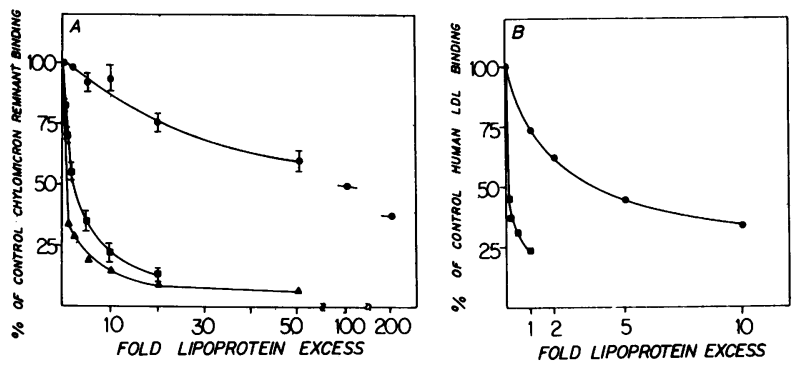

Figure 3. Competitive binding of human LDL and rat chylomicron remnants to $\mathrm{HTC}$ cells at $4^{\circ} \mathrm{C}$. $(A)$ Binding of rat ${ }^{125} \mathrm{I}$-chylomicron remnants. HTC cells were grown in complete medium and harvested as detailed in the legend to Fig. 1 and Methods. Binding assays contained $2.64 \mu \mathrm{g}{ }^{125} \mathrm{I}$-chylomicron remnant protein per milliliter (specific activity equals $1,220 \mathrm{cpm} / \mathrm{ng}$ ) and the indicated amounts of nonradioactive human $\mathrm{LDL}$, rat $\mathrm{HDL}_{c}$, or chylomicron remnants (1.0-fold equals $2.64 \mu \mathrm{g}$ lipoprotein $/ \mathrm{ml})$. Incubations were started by the addition of $3.9 \times 10^{5} \mathrm{HTC}$ cells per 200- $\mu$ incubations and continued for $1 \mathrm{~h}$ at $4^{\circ} \mathrm{C}$ with shaking. Competing lipoproteins were: $\mathrm{a}$, rat chylomicron remnants; $\triangle$, rat $\mathrm{HDL}_{c} ; \bullet$, human $\mathrm{LDL}$. The $100 \%$ control value was $56 \mathrm{ng}{ }^{125} \mathrm{I}$-chylomicron remnants bound $/ 10^{6}$ cells. $(B)$ Binding of human ${ }^{125} \mathrm{I}-\mathrm{LDL}$. HTC cells were grown in LDM for $20 \mathrm{~h}$ and harvested. Binding assays contained $53.8 \mu \mathrm{g}{ }^{125} \mathrm{I}-\mathrm{LDL}$ protein/ml (specific activity equals $284 \mathrm{cpm} / \mathrm{ng}$ ) and the indicated amounts of nonradioactive human LDL or chylomicron remnants (1.0-fold equals $53.8 \mu \mathrm{g} / \mathrm{ml}$ ). Incubations were performed as in $A$. Competing lipoproteins were: $\bullet$, rat chylomicron remnants; $\bullet$, human LDL. The $100 \%$ control value was $144 \mathrm{ng}{ }^{125} \mathrm{I}-\mathrm{LDL}$ bound $/ 10^{6}$ cells.

$20 \mathrm{~h}$ before the binding experiments in $0.5 \mu \mathrm{M}$ compactin to deplete their supply of endogenously synthesized cholesterol and to maximize the stimulus for receptor expression.

The binding of remnants at $4^{\circ} \mathrm{C}$ to HTC cells grown in complete medium or in LDM with compactin is shown in Fig. $4 \mathrm{~A}$. In both cases, binding at $4^{\circ} \mathrm{C}$ approached saturation at $\sim 10 \mu \mathrm{g}$ remnant protein $/ \mathrm{ml}$ and exhibited half maximal binding at $2-3 \mu \mathrm{g} / \mathrm{ml}$. However, whereas cells grown in complete medium had an average maximal binding of $66 \mathrm{ng}$ remnants $/ 10^{6}$ cells, those grown in LDM had an average maximal binding of 105 $\mathrm{ng} / 10^{6}$ cells, i.e. a 1.7 -fold increase in remnant binding. A similar increase in the amount of cell-associated radioactivity was observed at $37^{\circ} \mathrm{C}$ as shown in Fig. $4 \mathrm{~B}$. At this temperature, the binding and internalization were not saturated over the remnant concentration used and the variability between different experiments was large. However, in paired experiments performed on the same day, the ratio of binding of ${ }^{125} \mathrm{I}$-remnants at $10 \mu \mathrm{g}$ protein/ml by cells grown in LDM to that of cells grown in complete medium was equal to $1.7 \pm 0.2(n=5)$. This increase is the same as that observed at $4^{\circ} \mathrm{C}$ for binding alone. Despite the increase in maximal binding in $\mathrm{LDM}$ at $4^{\circ} \mathrm{C}$, half maximal binding was achieved at a similar concentration by cells grown in either type of medium. The same conclusions are drawn from the binding data analyzed by the method of Scatchard (44). At $4^{\circ} \mathrm{C}$ the extrapolated total binding in LDM compared with that in complete medium increased 1.6 -fold ( 154 vs. $96 \mathrm{ng} / 10^{6}$ cells), but the affinity of this binding did not change significantly (dissociation constant $\left.\left[K_{\mathrm{d}}\right]=3.8 \mathrm{vs} .4 .8 \mu \mathrm{g} / \mathrm{ml}\right)$.

The binding of human ${ }^{125} \mathrm{I}-\mathrm{LDL}$ to HTC cells grown in complete medium or LDM containing compactin was also compared (Fig. 5). At $4^{\circ} \mathrm{C}$ the LDL binding did not show complete saturation, even at $250 \mu \mathrm{g} \mathrm{LDL} / \mathrm{ml}$. Cells grown in LDM showed a mean 3.1-fold increase in human LDL binding at each lipoprotein concentration, as compared with cells grown in complete medium (Fig. 5). Scatchard analysis of the LDL binding data at $4^{\circ} \mathrm{C}$ revealed an increase in the extrapolated maximum binding in LDM (200 vs. $115 \mathrm{ng} \mathrm{LDL} / 10^{6}$ cells). There was also an $\sim$ twofold increase in the apparent affinity of this binding by cells grown in LDM plus compactin $\left(K_{d}\right.$ $=233 \mathrm{vs} .435 \mu \mathrm{g} / \mathrm{ml}$ ). Thus, the number of receptors increased by culturing cells under these conditions. Although there are several possible explanations for the altered $K_{d}$, the simplest may be that when the cells are grown in complete medium and assayed at $4^{\circ} \mathrm{C}$, the total LDL binding is so low that accurate separation of specific and nonspecific components is difficult. This might also explain the lower EDTA sensitivity for the binding under these conditions.
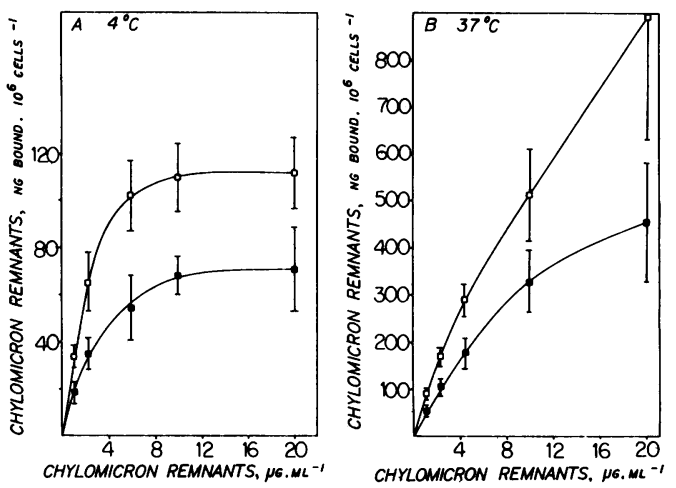

Figure 4. Comparison of the binding of rat chylomicron remnants to HTC cells grown in complete medium and in LDM. HTC cells were grown in complete medium, harvested, and resuspended at circa 3 $\times 10^{5}$ cells $/ \mathrm{ml}$ in $100 \mathrm{ml}$ of either complete medium or LDM containing $0.5 \mu \mathrm{M}$ compactin. After $20 \mathrm{~h}$ the cells were harvested, washed in PBS, and binding assays were performed using $3.9 \times 10^{5}$ cells in a $200 \mu \mathrm{l}$ vol, as detailed in Methods. The final ${ }^{125} \mathrm{I}$-chylomicron remnant concentrations were $1.2-20 \mu \mathrm{g}$ protein/ml (specific activity $200-450 \mathrm{cpm} / \mathrm{ng}$ ). For nonspecific binding the same incubation was carried out in the presence of $4 \mathrm{mM}$ EDTA and a 10-fold protein excess of unlabeled chylomicron remnants. Incubations were started by the addition of HTC cells and continued with shaking for $1 \mathrm{~h}$. Specific binding equals total binding-nonspecific binding. Specific binding is plotted as the mean \pm SE for 5-8 experiments. $(A)$ Binding at $4^{\circ} \mathrm{C}: \mathrm{HTC}$ cells grown in complete medium $\left(K_{\mathrm{d}}=4.8\right.$ $\mu \mathrm{g} \cdot \mathrm{ml}^{-1}, \mathrm{R}_{\mathrm{T}}=96 \mathrm{ng}$ bound per $10^{6}$ cells); $\square$, HTC cells grown in LDM with $0.5 \mu \mathrm{M}$ compactin $\left(K_{\mathrm{d}}=3.8 \mu \mathrm{g} \cdot \mathrm{ml}^{-1}, \mathrm{R}_{\mathrm{T}}=154 \mathrm{ng}\right.$ bound per $10^{6}$ cells). $(B)$ Binding at $37^{\circ} \mathrm{C}$. The experimental details and symbols are the same as in $A$. 

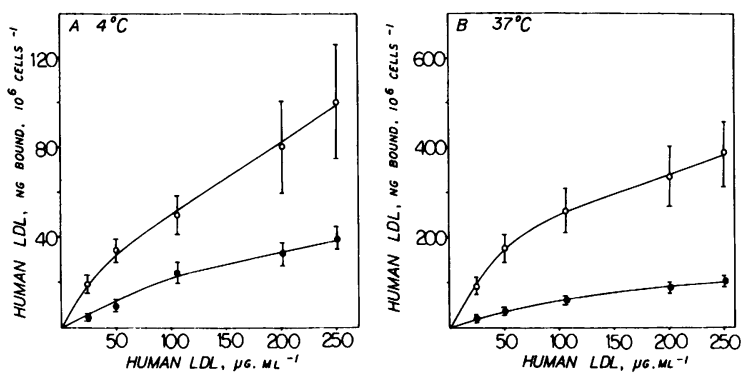

Figure 5. Comparison of the binding of human LDL to HTC cells grown in complete and in LDM plus compactin. HTC cells were grown as described in the legend to Fig. 1 and in Methods. The final LDL concentrations used in these experiments were 25-250 $\mu \mathrm{g}$ protein/ml (specific activity $200-390 \mathrm{cpm} / \mathrm{ng}$ ) and controls contained a 20 -fold excess of unlabeled LDL. Specific binding is plotted as the mean \pm SE for five experiments. Specific binding equals total binding minus binding in the presence of a 20 -fold protein excess of nonradioactive LDL. $(A)$ Binding at $4^{\circ} \mathrm{C}: \bullet, \mathrm{HTC}$ cells grown in complete medium $\left(K_{\mathrm{d}}=210 \mu \mathrm{g} \cdot \mathrm{ml}^{-1}, \mathrm{R}_{\mathrm{T}}=187 \mathrm{ng}\right.$ bound per $10^{6}$ cells $)$; $\mathrm{O}$, HTC cells grown in LDM with $0.5 \mu \mathrm{M}$ compactin $\left(K_{\mathrm{d}}=103\right.$ $\mu \mathrm{g} \cdot \mathrm{ml}^{-1}, \mathrm{R}_{\mathrm{T}}=525 \mathrm{ng}$ bound per $10^{6}$ cells). $(B)$ Binding at $37^{\circ} \mathrm{C}$. The experimental details and symbols are the same as in $A$.

From these experiments it is clear that the expression of specific binding sites for lipoproteins to HTC cells is responsive to growth conditions that are known to change cellular cholesterol metabolism (30).

Comparison of binding and internalization of rat $L D L$, human $L D L$, rat hypercholesterolemic very low density lipoprotein $(V L D L)$, and chylomicron remnants. Because it is difficult to obtain adequate amounts of pure rat LDL to carry out extensive studies, human LDL was used in most experiments. However, species differences exist for lipoprotein binding. Accordingly, comparative studies were carried out using rat LDL to insure that species differences would not change the interpretation of our results. In the preparation of rat LDL used, $<3 \%$ of the visibly stained protein was apo $\mathrm{E}$. Rat $\mathrm{LDL}$ uptake at $37^{\circ} \mathrm{C}$ was saturable, specific, and required calcium. It was increased by culturing the cells in LDM that contained compactin (Fig. 6 $A$ ). These characteristics are shared with human LDL (Fig. 5). The affinity for rat LDL was between 1.5- and 5-fold greater than for human LDL, depending upon the growth conditions of the cells. This is consistent with reports from other laboratories using fibroblasts $(41,42)$, although the magnitude of the difference observed here was somewhat less than reported.

In addition, the metabolism of two types of rat VLDL by these cells was studied. VLDL from normal fed rats displayed saturable specific uptake that increased about fivefold when cells were grown in LDM with compactin (Fig. 6 B). VLDL from rats fed an atherogenic diet (32) exhibited saturable specific uptake that increased 1.8-fold when cells were grown in LDM with compactin and had a 10-fold higher affinity compared with VLDL from rats fed a normal diet (Fig. $6 C$ ). Competitive inhibition curves with rat LDL as the radiolabeled ligand are shown in Fig. 7. In terms of ability to compete for rat LDL binding, chylomicron remnants had the greatest potency while rat LDL was more potent than human LDL. In experiments with human ${ }^{125} \mathrm{I}-\mathrm{LDL}$ as the radiolabeled ligand there was a similar competitive pattern of uptake, with rat LDL more effective than human LDL (not shown).

These experiments justify the use of human LDL for qualitative binding comparisons but confirm that, as suggested by others $(41,42)$, the results cannot be quantitatively interchanged with those of rat LDL. They also demonstrate that the cholesterol-rich VLDL of rats fed an atherogenic diet is a ligand for the receptor on these cells.

Degradation of lipoproteins. Degradation of each type of lipoprotein used in these experiments was determined by measuring the time-dependent appearance of ${ }^{125}$ I-labeled degradation products in the media. Each class of lipoprotein, rat LDL, human LDL, rat chylomicron remnants, and rat VLDL was degraded by the cells (Fig. 8). The relative rates of degradation reflected their relative uptake affinities.

Effect of lipoproteins on cholesterol biosynthesis by HTC

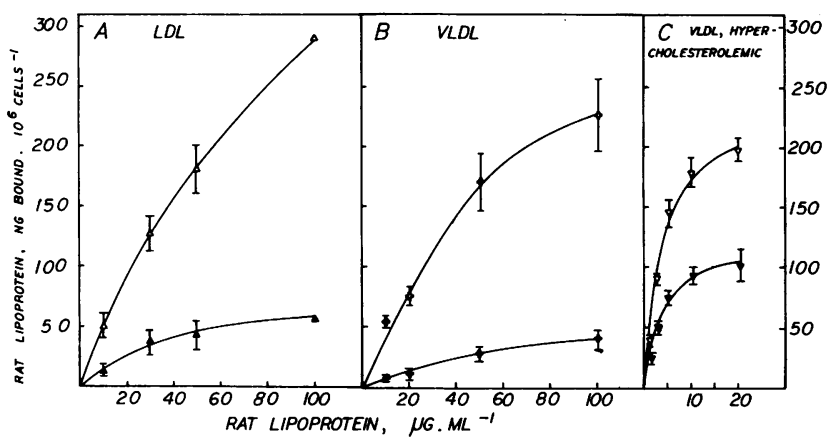

Figure 6. Binding of rat LDL and rat VLDL to HTC cells grown in complete medium and in LDM plus compactin. HTC cells were grown as described in the legend to Fig. 1 and in Methods. Binding assays were performed at $37^{\circ} \mathrm{C}$ as described in the legend to Fig. 1 . (A) Rat LDL. The final rat ${ }^{125} \mathrm{I}-\mathrm{LDL}$ concentrations were $10-100 \mu \mathrm{g}$ protein/ml (specific activity $161 \mathrm{cpm} / \mathrm{ng}$ ). Specific binding equals total binding-nonspecific binding in the presence of $4 \mathrm{mM}$ EDTA (70$75 \%$ of total binding). It is plotted as the mean \pm SE for three experiments. $\triangle$, HTC cells grown in complete medium; $\triangle$, HTC cells grown in LDM with $0.5 \mu \mathrm{M}$ compactin. (B) VLDL from rats fed a normal diet. VLDL was prepared from rats fed a normal diet as detailed in Methods. The final concentrations of rat ${ }^{125} \mathrm{I}$-VLDL were 10-200 $\mu \mathrm{g}$ protein $/ \mathrm{ml}$ (specific activity $72 \mathrm{cpm} / \mathrm{ng}$ ). Specific binding equals total minus nonspecific binding in the presence of $4 \mathrm{mM}$ EDTA or minus a 10-fold protein excess of nonradioactive VLDL (similar values were obtained with either of these two controls). Specific binding (75-90\% of total binding) is plotted as the mean \pm SE for three experiments. ,+ HTC cells grown in complete medium; \&, HTC cells grown in LDM plus $0.5 \mu \mathrm{M}$ compactin. (C) VLDL from rats fed an atherogenic diet. The final concentrations of rat hypercholesterolemic ${ }^{125} \mathrm{I}$ VLDL were $1.25-20 \mu \mathrm{g}$ protein $/ \mathrm{ml}$ (specific activity $819 \mathrm{cpm} / \mathrm{ng}$ ). Specific binding as defined in the legend to Fig. $6 B$ is plotted as the mean \pm SE for three experiments. $\nabla$, HTC cells grown in complete medium; $\nabla$, HTC cells grown in LDM plus $0.5 \mu \mathrm{M}$ compactin. 


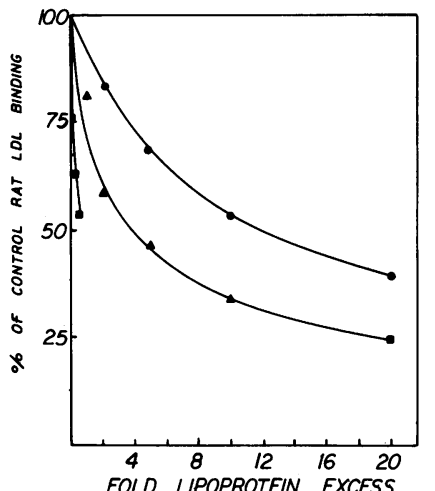

Figure 7. Competitive binding of rat ${ }^{125}$ I-LDL. HTC cells were grown in complete medium and harvested as detailed in the legend to Fig. 1 and in Methods. Binding assays contained $30 \mu \mathrm{g}$ of rat ${ }^{125}$ I-LDL protein/ml (specific activity $161 \mathrm{cpm} / \mathrm{ng}$ ) and the indicated amounts of nonradioactive lipoproteins (1.0-fold equals 30 $\mu \mathrm{g}$ lipoprotein $/ \mathrm{ml}$ ). Incubations were started by the addition of $3.75 \times 10^{5}$ HTC cells per 200 $\mu l$ incubation and continued

for $1 \mathrm{~h}$ at $37^{\circ} \mathrm{C}$ with stirring. Competing lipoproteins were: $\Delta$, rat LDL; $\bullet$, human LDL; $\boldsymbol{a}$, rat chylomicron remnants. The $100 \%$ control value was $88 \mathrm{ng}$ rat ${ }^{125} \mathrm{I}-\mathrm{LDL}$ bound $/ 10^{6}$ cells.

cells. Having established that HTC cells could bind and degrade lipoproteins, it was next important to examine the effect of these lipoproteins on cholesterol biosynthesis. Cells were cultured in either complete medium or LDM and then were resuspended in either complete medium or LDM. After $3 \mathrm{~h}$ of incubation in resuspension medium, $\left[{ }^{14} \mathrm{C}\right]$ acetate was added and the cells were incubated for an additional $7 \mathrm{~h}$. The amount of acetate incorporated into cholesterol was then determined. The results are shown in Table I. HTC cells grown and incubated in complete medium had a mean rate of $\left[{ }^{14} \mathrm{C}\right]$ acetate incorporation into cholesterol of $18,900 \mathrm{cpm} / 10^{7}$ cells per $7 \mathrm{~h}$ (line 1 ). Similar results were obtained when the cells were grown in LDM and resuspended in complete medium (line 4$)$. In contrast, HTC cells resuspended in LDM had a significantly greater $(P<0.001)$ rate of $\left[{ }^{14} \mathrm{C}\right]$ acetate incorporation into cholesterol. The rate was the same regardless of whether they were initially grown in complete medium or LDM before resuspension in LDM (lines 2 and 3). These results verified that the rate of cholesterol biosynthesis by HTC cells in culture can be rapidly modulated by variation in the cholesterol content of the medium.

Inclusion of chylomicron remnants at 20-30 $\mu \mathrm{g}$ cholesterol/ $\mathrm{ml}$ reduced the rate of $\left[{ }^{14} \mathrm{C}\right]$ acetate incorporation by cells grown in LDM and resuspended in LDM to a level comparable to that of cells grown and resuspended in complete medium (line 6 compared with line 1). Human LDL, which bound much less efficiently to the HTC cells, reduced $\left[{ }^{14} \mathrm{C}\right]$ acetate incorporation into cholesterol by $\sim 25 \%$ (line 8 , compared with line 3 ). The amount of inhibition was independent of cholesterol concentration over the range of 53-292 $\mu \mathrm{g}$ LDL cholesterol per milliliter.

When cells were transferred to LDM at the start of a 3-h incubation, the inclusion of remnants in the medium prevented the increase in $\left[{ }^{14} \mathrm{C}\right]$ acetate incorporation (line 5 , compared with lines 1 and 2), whereas the inclusion of human LDL (line 7 compared with lines 1 and 2) did not. Thus, chylomicron remnants both returned cholesterol synthetic levels in cells grown in LDM to the level seen in complete medium and prevented the rise induced by transfer from complete medium to LDM.
In contrast, human LDL only partially reduced the cholesterol synthetic rate of cells grown in LDM and did not prevent the rise induced when cells were transferred from complete to LDM. These findings are consistent with the binding data and confirm the concept that the amount of cholesterol to which the HTC cells are exposed is not per se the crucial factor in regulating cholesterol biosynthesis, but rather it is the ability of the cell to bind and transport the particular lipoprotein particle involved that is important.

When either remnants (line 9) or human LDL (line 10) were added at the highest concentrations used in the previous experiments to HTC cells grown and resuspended in complete medium, there was no suppression of $\left[{ }^{14} \mathrm{C}\right]$ acetate incorporation into cholesterol to a level below that seen in cells grown in complete medium (line 1). The same was true when the entire lipoprotein-enriched fraction derived from the upper layer of calf serum (density 1.21) was used, even though it contained 2.5 times the cholesterol content of complete medium (line 11). Two possibilities exist to explain this failure to suppress cholesterol synthesis to a level below the base line that was expressed by culture in complete medium. Either the cells simply cannot lower their rate of synthesis any further, which would constitute an abnormality of the intracellular mechanism for feedback inhibition, or the number of receptors expressed in the presence of serum is inadequate to transport sufficient cholesterol in chylomicron remnants to suppress synthesis further. To distinguish between these possibilities, the abnormal VLDL from hypercholesterolemic rats were used. These lipoproteins contain substantially more cholesterol per particle than do chylomicron remnants $(32,34)$, and are bound and degraded by HTC cells (Figs. 6 and 8). As would be expected, if the number of lipoprotein receptors was limiting the amount of cholesterol entering the cell, $\left[{ }^{14} \mathrm{C}\right]$ acetate incorporation into cholesterol in the presence of hypercholesterolemic VLDL was suppressed below the level present in cells grown in complete medium (Table I, line 12 compared with line 1). This suppression was dose dependent

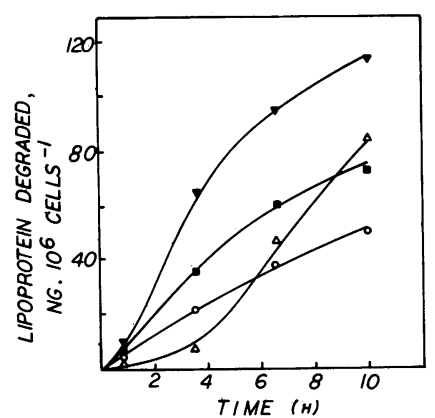

Figure 8. Lipoprotein degradation by HTC cells. HTC cells growing in complete medium $\left(40 \mathrm{ml}\right.$ at $6 \times 10^{5}$ cells $\left./ \mathrm{ml}\right)$ were harvested and degradation experiments performed as detailed in Methods. Incubations were started by the addition of ${ }^{125}$ I-labeled lipoproteins and continued at $37^{\circ} \mathrm{C}$ with stirring. Control incubations for the experiments shown here did not contain any HTC cells. The ordinate plots TCA soluble counts not extracted into chloroform as nanogram degraded lipoprotein per $10^{6}$ cells (experimentalcontrol incubations). Lipoprotein degradation by cells at $6^{\circ} \mathrm{C}$ was minimal. $₫$, rat chylomicron remnants, $2 \mu \mathrm{g} / \mathrm{ml} ; \Delta$, rat LDL, $10 \mu \mathrm{g} /$ $\mathrm{ml} ; \mathrm{v}$, rat hypercholesterolemic VLDL, $2 \mu \mathrm{g} / \mathrm{ml}$; o, human LDL, 10 $\mu \mathrm{g} / \mathrm{ml}$. 
Table I. Incorporation of $\left[{ }^{14} \mathrm{C}\right]$ Acetate into Cholesterol by HTC Cells

\begin{tabular}{llllc}
\hline Growth medium & Resuspension medium & Lipoprotein added & ['CC]Acetate incorporation into cholesterol \\
\hline & & & $c p m / 10^{\prime}$ cells $/ 7 h$ \\
1. Complete & Complete & None & $18,870 \pm 740$ & $(n=18)$ \\
2. Complete & Lipid depleted & None & $46,450 \pm 7,500$ & $(n=3)^{*}$ \\
3. Lipid depleted & Lipid depleted & None & $44,400 \pm 2,970$ & $(n=9)^{*}$ \\
4. Lipid depleted & Complete & None & 21,970 & $(n=1)$ \\
5. Complete & Lipid depleted & CR & 23,615 & $(n=2)$ \\
6. Lipid depleted & Lipid depleted & CR & $20,320 \pm 2,390$ & $(n=3)$ \\
7. Complete & Lipid depleted & LDL & 33,450 & $(n=1)$ \\
8. Lipid depleted & Lipid depleted & LDL & $32,790 \pm 3,450$ & $(n=3)$ \\
9. Complete & Complete & CR & $20,610 \pm 1,290$ & $(n=4)$ \\
10. Complete & Complete & LDL & 19,900 & $(n=1)$ \\
11. Complete & Complete & Total serum lipoproteins & 22,050 & $(n=2)$ \\
12. Complete & Complete & Hypercholesterolemic VLDL & $11,500 \pm 790$ & $(n=6)^{*}$ \\
& & & &
\end{tabular}

HTC cells were grown in complete medium or LDM for $20 \mathrm{~h}$, harvested and resuspended in fresh complete medium or LDM. They were incubated for $3 \mathrm{~h}$ in the presence of the indicated lipoproteins, and then $\left[{ }^{14} \mathrm{C}\right]$ acetate $(2 \mu \mathrm{Ci} / \mu \mathrm{mol}$, final concentration $0.2 \mathrm{mM})$ was added and the incubation continued for $7 \mathrm{~h}$. After the addition of ${ }^{3} \mathrm{H}$-cholesterol as an internal standard, the suspensions were saponified, extracted with petroleum ether, and the cholesterol was isolated by thin layer chromatography as described in Methods. Lipoprotein concentrations after resuspension in LDM were: chylomicron remnants (CR) 7-10 $\mu \mathrm{g}$ protein $/ \mathrm{ml}$ with 20-30 $\mu \mathrm{g}$ cholesterol/ml; human LDL 50-110 $\mu \mathrm{g}$ protein/ml with 130-290 $\mu \mathrm{g}$ cholesterol/ml. Concentrations of lipoproteins in resuspensions with complete medium were: chylomicron remnants $10 \mu \mathrm{g}$ protein/ $\mathrm{ml}$ with $30 \mu \mathrm{g}$ cholesterol $/ \mathrm{ml}$; human LDL $110 \mu \mathrm{g}$ protein $/ \mathrm{ml}$ with $290 \mu \mathrm{g}$ cholesterol $/ \mathrm{ml}$; hypercholesterolemic VLDL $30 \mu \mathrm{g}$ protein/ml with $105 \mu \mathrm{g}$ cholesterol $/ \mathrm{ml}$; total calf serum lipoprotein $45 \mu \mathrm{g} / \mathrm{ml} . n=$ number of experiments. Results \pm SEM are given. ${ }^{*}$ Significantly different from line $1(P<0.001)$.

over the range of $35-113 \mu \mathrm{g}$ cholesterol/ml (data not shown). Thus, these studies provide no support for the presence of an intrinsic defect in the mechanism of the regulation of cholesterol biosynthesis. Rather, they suggest that the degree of regulation of cholesterol biosynthesis in a hepatoma cell by lipoproteins is more likely to be determined by the nature and number of lipoprotein receptors expressed by the cell in vivo, and, other factors being equal, by the amount of cholesterol within each lipoprotein particle.

Comparison of remnant binding to cell membranes from hepatomas and normal liver. Based on the above data, the hypothesis that the deletion of feedback inhibition seen in hepatomas in vivo is due to a diminished ability to transport chylomicron remnants as compared with normal liver, continued to be plausible. To test whether there were fewer receptors expressed on hepatomas than on normal liver in vivo, cell membranes were prepared from normal livers, livers of rats bearing hepatomas, hepatomas that had been implanted intramuscularly or subcutaneously, and hepatoma cells grown in vitro. The ability of each of these preparations to specifically bind chylomicron remnants was measured. The assay was similar to that reported by Kovanen et al. (45) and used by Hui et al. (46). There was no significant difference in binding between membranes of liver from normal rats and the liver of tumor-bearing animals (Fig. 9). However, the membranes from tumors themselves bound significantly fewer remnants than did either liver preparation $(P<0.001)$. The membranes from intramuscularly grown tu- mors bound slightly fewer remnants than those from tumors grown subcutaneously in the same animal. Membranes from the hepatoma cells that had been grown in vitro bound significantly fewer remnants than those from either normal livers or subcutaneously grown tumors. They also bound fewer remnants than intramuscularly grown tumors, but this difference was not statistically significant. Maximal binding to membranes from intramuscularly grown tumors was $\sim 30 \%$ of that to normal liver. No significant differences in binding affinities, as determined by the slopes of the Scatchard plots, were noted (Fig. 9 B).

These data support the concept that hepatomas express substantially fewer receptors capable of binding chylomicron remnants than does normal liver. When considered along with the in vitro experiments, these data add strong support to the hypothesis that the lack of feedback inhibition in hepatomas is due at least in part to a diminished capacity of the tumor to transport lipoproteins of dietary origin as compared with normal liver.

\section{Discussion}

Cholesterol is an essential component of all mammalian cell membranes and, as such, regulation of its synthesis and metabolism is of prime importance for cellular growth and function. The demonstration of loss of regulation of cholesterol biosynthesis by dietary cholesterol in a variety of liver neoplasms (14- 


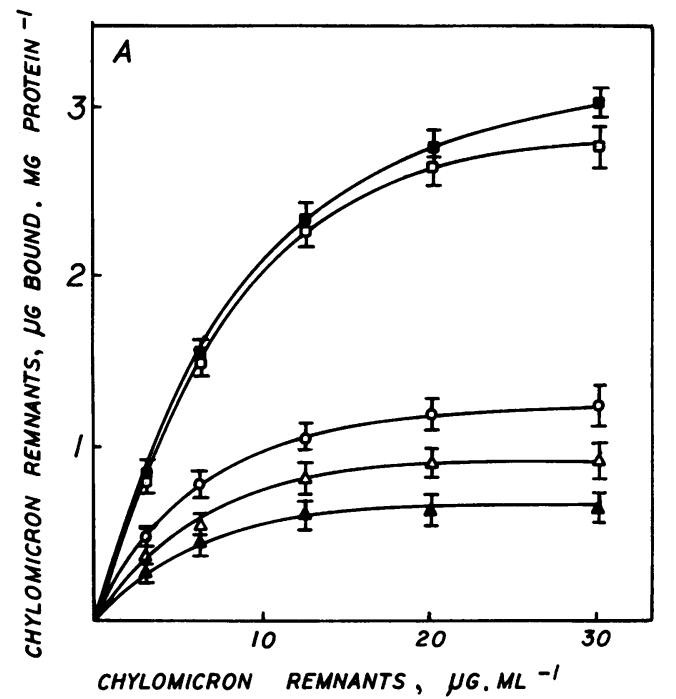

Figure 9. Binding of $\left[{ }^{125} \mathrm{I}\right]$ chylomicron remnants to cell membranes. Cell membranes were prepared from livers of control rats $(n=5)$, livers of tumor-bearing rats $(n=7)$, subcutaneous tumors $(n=7)$, intramuscular tumors $(n=7)$, and batches of HTC cells in vitro $(n=$ 4) as detailed in Methods. Incubations at $37^{\circ} \mathrm{C}$ for $1 \mathrm{~h}$ contained in a $200 \mu l$ total vol: $50 \mathrm{mM}$ Tris/HCl buffer $\mathrm{pH} 7.5,100 \mathrm{mM} \mathrm{NaCl}, 0.5$ $\mathrm{mM} \mathrm{CaCl}_{2}, 150-180 \mu \mathrm{g}$ protein in cell membranes, and ${ }^{125} \mathrm{I}$-chylomicron remnants, (specific activity $360 \mathrm{cpm} / \mathrm{ng}$ ). Control incubations contained a 15 times protein excess of nonradioactive chylomicron remnants or $0.2 \mathrm{mM}$ suramin. Specific binding was determined as described in Methods and is plotted in $A$ as micrograms ${ }^{125}$ I-chylomicron remnants bound per milligram cell membrane protein vs. the chylomicron remnant concentration in micrograms per milliliter. The

18) led to the hypothesis that this regulatory defect was associated with the etiology or pathogenesis of the malignant state (15). Thus, it became important to identify precisely which step in the regulatory pathway of cholesterol metabolism was aberrant.

Evidence has been provided that many of the intracellular events in the regulation of cholesterol biosynthesis are intact in these cells $(22,25)$, and that uptake of intragastrically administered cholesterol by tumors was less than by liver (23). Accordingly, we hypothesized that the abnormality in regulation relates to the delivery of cholesterol to the cell as modulated by the number, type, or affinities of the lipoprotein receptors present on the plasma membrane of the hepatoma cells as compared with those of normal hepatocytes. The present studies first used hepatoma cells in tissue culture to characterize the lipoprotein receptors present. Tissue culture was chosen because it affords rigid control of the cells' environment and circumvents problems of access of lipoproteins to the cells. From the work reported here it is clear that HTC cells do express lipoprotein receptors on their cell surface when grown in culture. These receptors bind rat chylomicron remnants, rat $L D L$, human $L D L$, and rat VLDL, and these lipoproteins are internalized and degraded. Chylomicron remnant binding has recently been shown to be present in at least one other hepatoma cell line (47). Thus, same batch of chylomicron remnants was used in these experiments. Mean \pm SEM is shown. $a$, liver membranes from control rats; $\square$, liver membranes from rats bearing tumors; $O$, membranes from subcutaneously grown tumors; $\Delta$, membranes from intramuscularly grown tumors; $\Delta$ membranes from HTC cells in vitro. $(B)$ The data of Fig. $9 A$ are plotted as bound/free vs. bound chylomicron remnant concentration. $\omega$, liver from control and tumor-bearing rats $\left(K_{d}=12 \mu \mathrm{g}\right.$ chylomicron remnants/ml, maximum bound equals $4.36 \mu \mathrm{g}$ chylomicron remnants/mg protein; $\circ$, subcutaneous tumor $\left(K_{d}=7\right.$, max. $=$ 1.59); $\Delta$, intramuscular tumor $\left(K_{d}=9, \max =1.29\right)$; $\Delta$, HTC cells $\left(K_{\mathrm{d}}=6 \mu \mathrm{g}\right.$ chylomicron remnants $/ \mathrm{ml}$, maximum bound equals 0.8 $\mu \mathrm{g}$ chylomicron remnants/mg protein).

it appears that the abnormality in regulation of cholesterol synthesis is not due to a complete deletion of the ability of the hepatoma to bind or transport lipoproteins.

Instead, the above results suggest that the defect relates to the quantitative ability of these cells to bind and transport lipoproteins. The number of lipoprotein receptors expressed by HTC cells grown in the presence of calf serum was inadequate to facilitate the transport of sufficient cholesterol, carried by normal chylomicron remnants or human LDL, to result in suppression of $\left[{ }^{14} \mathrm{C}\right]$ acetate incorporation into cholesterol to a level below its base line. However, lipoproteins containing apo $\mathrm{E}$, which were highly enriched in cholesterol per particle, did suppress $\left[{ }^{14} \mathrm{C}\right]$ acetate incorporation into cholesterol below the base-line level, which demonstrated that cholesterol synthesis in these cells was indeed susceptible to further inhibition by lipoprotein-derived cholesterol.

The defect could also relate to the nature of the lipoprotein receptors present. Currently it is believed that liver can express at least two relatively distinct lipoprotein receptors. The first has been characterized extensively by Brown and Goldstein (43) in human skin fibroblasts and is referred to as the LDL or B,E receptor. This receptor requires $\mathrm{Ca}^{++}$for binding and its numbers on the cell surface can be regulated in response to changes in 
sterol metabolism. The second receptor, which is responsible for chylomicron remnant clearance, recognizes only apo $E$, is more resistant to EDTA, and is expressed at the same level regardless of the metabolic state of the liver $(11,32,48,49)$. Because both receptors recognize apo $\mathrm{E}$, both can transport chylomicron remnants, hence either receptor could be responsible for the ability of hepatomas to transport remnants as observed in this study. On the basis of the data in this report it is clear that these hepatomas express an LDL-type receptor. The receptors on these cells recognized human LDL, were $\mathrm{Ca}^{++}$dependent, and were induced by culturing in LDM in the presence of compactin. The question of whether there is also a remnant or apo E receptor could not be definitively resolved. On the one hand, the competitive binding studies, which revealed that LDL was able to displace only a portion of the remnant binding are consistent with the notion that there are at least some remnant-specific receptors on these cells. In less extensive studies, similar findings were made with purified rat LDL. However, the number of rats required for extensive studies with rat LDL was prohibitive, and the very high concentrations of LDL that might be needed to compete for the higher affinity apo $\mathrm{E}$ binding to the LDL receptor are toxic. Thus, definitive resolution of the exact nature of the lipoprotein receptor(s) on HTC cells will require the development of specific probes for the LDL and remnant receptors.

Having demonstrated that functional lipoprotein receptors are expressed in vitro, it became important to compare the number of receptors expressed by hepatoma cells in vitro with that expressed in vivo, and to compare this with the number of receptors expressed by normal liver. To do this, the binding of chylomicron remnants to cell membranes was studied. Consistent with our hypothesis, the binding of chylomicron remnants to liver membranes from either normal or tumor-bearing animals was several fold greater than that to tumor membranes. Although it is not certain whether this is due to a reduction or a complete absence of remnant receptors, a difference of this magnitude should significantly lower the ability of tumors to transport chylomicron remnants in vivo as compared with normal liver.

There were some differences in binding among various HTC cell preparations. Membranes from subcutaneously grown tumors had a greater binding capacity than those from in vitro grown hepatoma cells, while membranes from tumors grown intramuscularly were intermediate. This result suggests that the expression of lipoprotein receptors by a tumor cell can be regulated by its environment. This is consistent with the in vitro demonstration that the number of receptors could be increased by growing the cells in LDM with compactin.

From all of the above findings it is clear that hepatomas do express lipoprotein receptors. We postulate that a relative lack of lipoprotein receptors expressed by hepatomas in comparison with those on normal liver explains why hepatoma cells in vivo may not compete efficiently with normal liver for the remnants in the circulation after a cholesterol-containing meal, and therefore may explain why the tumors exhibit an apparent lack of feedback inhibition of cholesterol synthesis.

\section{Acknowledgments}

We would like to thank Dr. George Hahn for generous provision of tissue culture facilities, Robin Daus for excellent assistance with the preliminary experiments, Dr. Millie Wiley for the gift of compactin, Dr. John A. Watson for provision of HTC cells for the preliminary experiments, and Jan Wick and Jennifer Faravelli for typing the manuscript.

This work was supported in part by National Institutes of Health grants AM 18774 and HL 05360.

\section{References}

1. Gould, R. G. 1951. Lipid metabolism and atherosclerosis. Am. J. Med. 11:209-227.

2. Cooper, A. D. 1977. The metabolism of chylomicron remnants by isolated perfused rat liver. Biochim. Biophys. Acta. 488:464-474.

3. Sherrill, B. C., and J. M. Dietschy. 1978. Characterization of the sinusoidal transport process responsible for uptake of chylomicrons by the liver. J. Biol. Chem. 253:1859-1867.

4. Redgrave, T. G. 1970. Formation of cholesteryl ester-rich particulate lipid during metabolism of chylomicrons. J. Clin. Invest. 49:465471.

5. Cooper, A. D., S. K. Erickson, R. Nutik, and M. A. Shrewsbury. 1982. Characterization of chylomicron remnant binding to rat liver membranes. J. Lipid. Res. 23:42-52.

6. Sherrill, B. C., T. L. Innerarity, and R. W. Mahley. 1980. Rapid hepatic clearance of canine lipoproteins containing only the $\mathrm{E}$ apoprotein by a high affinity receptor. J. Biol. Chem. 255:1804-1807.

7. Windler, E., Y. Chao, and R. J. Havel. 1980. Determinants of hepatic uptake of the triglyceride-rich lipoproteins and their remnants in the liver. J. Biol. Chem. 255:5475-5480.

8. Shelbourne, F., J. Hank, W. Meyers, and S. Quarfordt. 1980. Effect of apoproteins on hepatic uptake of triglyceride emulsions in the rat. J. Clin. Invest. 65:652-658.

9. Floren, C.-H., and A. Nilsson. 1978. Uptake and degradation of iodine-labeled chylomicron remnant particles by monolayers of rat hepatocytes. Euro. J. Biochem. 80:331-340.

10. Floren, C.-H., H. Nordgren, and A. Nilsson. 1977. Effects of chloroquine and colchicine on the degradation of chyle cholesteryl ester and phospholipid in vivo. Euro. J. Biochem. 80:331-340.

11. Cooper, A. D., and P. Y. S. Yu. 1978. Rates of removal and degradation of chylomicron remnants by isolated perfused rat liver. $J$. Lipid Res. 19:635-643.

12. Goldstein, J. L., and M. S. Brown. 1973. Familial hypercholesterolemia; identification of a defect in the regulation of 3-hydroxy-3methylglutaryl coenzyme A reductase activity associated with overproduction of cholesterol. Proc. Natl. Acad. Sci. USA. 70:2804-2808.

13. Gould, R. G., and G. Popjak. 1957. Biosynthesis of cholesterol in vivo and in vitro from DL-3-hydroxy-3-methyl $\left[2-{ }^{14} \mathrm{C}\right]$ valerolactone. Biochem. J. 66:51P. (Abstr.)

14. Siperstein, M. D., and V. M. Fagan. 1966. Feedback control of mevalonate synthesis by dietary cholesterol. J. Biol. Chem. 241:602609.

15. Siperstein, M. D. 1970. Regulation of cholesterol biosynthesis in normal and malignant tissues. Curr. Top. Cell Regul. 2:65-100.

16. Siperstein, M. D., and V. M. Fagan. 1964. Deletion of the cholesterol-negative feedback system in liver tumors. Cancer Res. 24:11081115.

17. Horton, B. J., G. E. Mott, H. C. Pitot, and S. Goldfarb. 1973. 
Rapid uptake of dietary cholesterol by hyperplastic liver nodules and primary hepatomas. Cancer Res. 33:460-464.

18. Siperstein, M. D. 1966. Deletion of the cholesterol-negative feedback system in precancerous liver. J. Clin. Invest. 45:1073A. (Abstr.)

19. Brown, M. S., S. E. Dana, and M. D. Siperstein. 1974. Properties of 3-hydroxy-3-methylglutaryl coenzyme A reductase solubilized from rat liver and hepatoma. J. Biol. Chem. 249:6585-6589.

20. Gregg, R. G., J. R. Sabine, and P. A. Wilce. 1982. Regulation of 3-hydroxy-3-methylglutaryl coenzyme $A$ in rat liver and Morris hepatomas $5123 \mathrm{C}, 9618 \mathrm{~A}$, and 5123 t.c. Biochem. J. 204:457-462.

21. George, R., and S. Goldfarb. 1980. Inhibition of 3-hydroxy-3methylglutaryl coenzyme A reductase activity in Morris hepatoma 7800 after intravenous injection of mevalonic acid. Cancer Res. 40:47174721.

22. Bell, J. J., T. E. Sargeant, and J. A. Watson. 1976. Inhibition of 3-hydroxy-3-methylglutaryl coenzyme A reductase activity in hepatoma tissue culture cells by pure cholesterol and several cholesterol derivatives. J. Biol. Chem. 251:1745-1758.

23. Harry, D. S., H. P. Morris, and N. McIntyre. 1971. Cholesterol biosynthesis in transplantable hepatoma: evidence for impairment of uptake and storage of dietary cholesterol. J. Lipid Res. 12:313-317.

24. Mitchell, A. D., T. D. Pugh, and S. Goldfarb. 1978. Partial feedback control of 3-hydroxy-3-methylglutaryl coenzyme A reductase activity in primary hepatocellular carcinomas. Cancer Res. 38:44744477.

25. Bierne, O. R., and J. A. Watson. 1976. Comparison of regulation of 3-hydroxy-3-methylglutaryl coenzyme A reductase in hepatoma cells grown in vivo and in vitro. Proc. Natl. Acad. Sci. USA. 73:2735-2739.

26. Barnard, G. F., S. K. Erickson, and A. D. Cooper. 1982. Rat hepatoma cells have functional chylomicron remnant receptors. Clin. Res. 30:91A. (Abstr.)

27. Barnard, G. F., S. K. Erickson, and A. D. Cooper. 1983. Hepatomas in vivo have fewer chylomicron remnant receptors than normal liver. Clin. Res. 31:29A. (Abstr.)

28. Barnard, G. F., A. D. Cooper, and S. K. Erickson. 1982. Modulation of lipoprotein binding and cholesterol synthesis in hepatoma cells. Fed. Proc. 41:3677. (Abstr.)

29. Ishikawa, T. T., J. MacGee, J. A. Morrison, and C. J. Glueck. 1974. Quantitative analysis of cholesterol in 5 to $20 \mu$ l of plasma. $J$. Lipid Res. 15:286-287.

30. Brown, M. S., J. R. Faust, J. L. Goldstein, I. Kaneko, and A. Endo. 1978. Induction of 3-hydroxy-3-methylglutaryl coenzyme A reductase activity in human fibroblasts incubated with compactin (ML236B), a competitive inhibitor of the reductase. J. Biol. Chem. 253:11211128.

31. Cooper, A. D., and R. K. Ockner. 1974. Studies of hepatic cholesterol synthesis in experimental acute biliary cholestasis. Gastroenterology. 66:586-595.

32. Kris-Etherton, P. M., and A. D. Cooper. 1980. Studies on the etiology of the hyperlipidemia in rats fed an atherogenic diet. J. Lipid Res. 21:435-442.

33. Sigurdsson, G., S.-P. Noel, and R. J. Havel. 1978. Catabolism of the apoprotein of low density lipoproteins by the isolated perfused rat liver. J. Lipid Res. 19:628-634.

34. Van Zuiden, P. E. A., S. K. Erickson, and A. D. Cooper. 1983. The effect of lipoprotein composition on hepatic 3-hydroxy-3-methylglutaryl coenzyme A reductase activity and hepatic very low density lipoprotein secretion. J. Lipid Res. 24:418-428.

35. Chisholm, G. M., C. A. Sila, and S. P. Hmiel. 1981. Measurements of the degradation products of radio-iodinated proteins. Anal. Biochem. 111:212-219.

36. Dietschy, J. M., and J. D. Wilson. 1968. Cholesterol synthesis in the squirrel monkey: relative rates of synthesis in various tissues and mechanisms of control. J. Clin. Invest. 47:166-174.

37. Basu, S. K., J. L. Goldstein, and M. S. Brown. 1978. Characterization of the low density lipoprotein receptor in membranes prepared from human fibroblasts. J. Biol. Chem. 253:3852-3856.

38. Lowry, O. H., N. J. Rosebrough, A. L. Farr, and R. J. Randall. 1951. Protein measurement with the Folin phenol reagent. J. Biol. Chem. 193:265-275.

39. Schneider, W. J., U. Beisiegel, J. L. Goldstein, and M. S. Brown. 1982. Purification of the low density lipoprotein receptor, an acidic glycoprotein of 164,000 molecular weight. J. Biol. Chem. 257:26642673.

40. Floren, C.-H., J. J. Albers, B. J. Kudchodkar, and E. L. Bierman. 1981. Receptor-dependent uptake of human chylomicron remnants by cultured skin fibroblasts. J. Biol. Chem. 256:425-433.

41. Innerarity, T. L., R. E. Pitas, and R. W. Mahley. 1980. Disparities in the interaction of rat and human lipoproteins with cultured rat $\mathrm{fi}-$ broblasts and smooth muscle cells. J. Biol. Chem. 255:11163-11172.

42. Drevon, C. A., A. D. Attie, S. H. Pangburn, and D. Steinberg. 1981. Metabolism of homologous and heterologous lipoproteins by cultured rat and human skin fibroblasts. J. Lipid Res. 22:37-46.

43. Goldstein, J. L., and M. S. Brown. 1977. The low density lipoprotein pathway and its relation to atherosclerosis. Annu. Rev. Biochem. 46:897-930.

44. Scatchard, G. 1949. The attractions of proteins for small molecules and ions. Ann. NY. Acad. Sci. 51:660-672.

45. Kovanen, P. T., S. K. Basu, J. L. Goldstein, and M. S. Brown. 1979. Low density lipoprotein receptors in bovine adrenal cortex. Low density lipoprotein binding to membranes prepared from fresh tissue. Endocrinology. 104:610-616.

46. Hui, D. Y., T. L. Innerarity, and R. W. Mahley. 1981. Lipoprotein binding to canine hepatic membranes. J. Biol. Chem. 256:5646-5655.

47. Pattnaik, N. M., and D. B. Zilversmit. 1980. Effect of size and competition by lipoproteins and apolipoproteins on the uptake of chylomicrons and chylomicron remnants by hepatoma cells in culture. Biochim. Biophys. Acta. 617:335-346.

48. Ross, A. C., and D. B. Zilversmit. 1977. Chylomicron remnant cholesteryl esters as the major constituent of very low density lipoproteins in plasma of cholesterol-fed rabbits. J. Lipid Res. 18:169-181.

49. Redgrave, T. G., and D. A. Snibson. 1977. Clearance of chylomicron triacylglycerol and cholesteryl ester from the plasma of streptozotocin-induced diabetic and hypercholesterolemic hypothyroid rats. Metab. 26:493-503. 